\title{
Global incidence of sudden cardiac arrest in young athletes and military members: a systematic review and meta-analysis
}

\author{
Aaron Lear MD, MSc; Cleveland Clinic Akron General, Akron, OH USA \\ Niraj Patel, DO HeyDoctor by GoodRx, San Francisco, CA USA \\ Chanda Mullen, PhD; Cleveland Clinic Akron General, Akron, OH USA \\ Marian Simonson, MS; Cleveland Clinic Foundation, Cleveland, OH USA \\ Vince Leone, MD; Northeast Ohio Medical University (NEOMED), Akron, OH USA \\ Constantinos Koshiaris, PhD; University of Oxford, Oxford, UK \\ David Nunan, PhD; University of Oxford, Oxford, UK Twitter: @dnunan79
}

Word Count: 4077

Contact author:

Aaron Lear

1 Akron General Way

Ctr for Fam Medicine

Akron, $\mathrm{OH} 44307$ USA

ORCID iD: 0000-0002-1353-7785

leara@ccf.org

office: 330.344 .6047 (Angela Watkins assistant) 


\section{Abstract}

Objectives: The goals of this review are to evaluate the quality of the evidence on the incidence of sudden cardiac arrest and death (SCA/D) in athletes and military members; and to estimate annual incidence of SCA/D.

Data Sources: MEDLINE, Embase, Cochrane CENTRAL, Web of Science, BIOSIS, Scopus, SPORT discus, PEDro, and clinicaltrials.gov were searched from inception to dates between 2/21/19 and $7 / 29 / 19$.

Study Selection: Studies which reported incidence of SCA/D or both in athletes, or military members under age 40 were eligible for inclusion. 40 studies were identified for inclusion

Data Extraction: Risk of bias was assessed using a validated, customized tool for prevalence studies in all included studies. 12 were found to be low ROB, with the remaining 28 moderate or high ROB. Data was extracted for narrative review, and meta-analysis.

Data Synthesis: Random-effects meta-analysis was performed in studies judged to be low risk of bias in two separate categories: 5 studies on regional or national level data including athletes at all levels, and both sexes included 130 events of SCD, with a total of 11,272,560 athlete years showing a cumulative incidence rate of 0.98 [95\% Cl: $0.62,1.53]$ per 100,000 athlete years, with high heterogeneity with $I^{2}$ of $78 \%$; 3 Studies focusing on competitive athletes between the ages of 14 and 25 were combined, and included 183 events, and 17,798758 athlete years showing an incidence rate of $1.91[95 \% \mathrm{Cl}: 0.71 ; 5.14]$ per 100,000 athlete years with high heterogeneity with $l^{2}$ of $97 \%$.

Conclusion: The worldwide incidence of SCD is a rare event. Low risk of bias studies indicate levels of SCD to be below 2 per 100,000 athlete years. Overall, the quality of the evidence available on the subject of SCA/D is low, but there are high quality individual studies to inform the question of incidence levels.

PROSPERO Registration: CRD42019125560

Keywords: athletes, military, sudden cardiac arrest, sudden cardiac death, incidence

Abstract word count: 298

Manuscript word count: 4059 
medRxiv preprint doi: https://doi.org/10.1101/2020.09.13.20193714; this version posted December 24, 2020. The copyright holder for this preprint (which was not certified by peer review) is the author/funder, who has granted medRxiv a license to display the preprint in perpetuity. It is made available under a CC-BY-NC-ND 4.0 International license.

\section{Key Points:}

There are several published articles which give a clear picture on the estimate of sudden cardiac arrest and death in athletes and military members, but the overall state of the literature has substantial risk of bias, with only 12 of 40 included articles at low risk of bias.

Meta-analysis of sudden cardiac death was shown to be rare overall in athletes, with high quality, large population level studies synthesized to show a rate of $0.98[95 \% \mathrm{Cl}: 0.62,1.53]$ per 100,000 athlete years, and more focused studies on competitive younger athletes synthesized to show a rate $1.91[95 \% \mathrm{Cl}: 0.71 ; 5.14]$ per 100,000 athlete years. There was high heterogeneity present in both meta-analyses. 
medRxiv preprint doi: https://doi.org/10.1101/2020.09.13.20193714; this version posted December $24,2020$. The copyright holder for this preprint (which was not certified by peer review) is the author/funder, who has granted medRxiv a license to display the preprint in perpetuity.

It is made available under a CC-BY-NC-ND 4.0 International license .

\section{Introduction}

Sudden cardiac arrest (SCA) leading to death has been shown to be the leading medical cause of death in young competitive athletes ${ }^{1}$. It is believed that exercise and physical activity amongst athletes can lead to episodes of arrhythmia leading to sudden death ${ }^{2}$. The topic of screening athletes with electrocardiograms in order to prevent sudden cardiac arrest and death (SCA/D) has become a controversial topic in sports medicine ${ }^{3,4}$. Authors have pointed out that the overall burden of sudden cardiac death (SCD) remains low, around 1 event per 100,000 athletes/year or less ${ }^{3}$, while others believe the incidence of SCA/D to be chronically undercounted $^{5}$, and suggest that screening may decrease the incidence of SCA/D. A lack of consensus on methods to attribute sudden deaths to cardiovascular causes further confuses the issue. Surveys of high schools and universities ${ }^{6,7}$; search of newspaper and web based reports $^{8,9}$; use of national health and autopsy records ${ }^{10-12}$; catastrophic insurance records ${ }^{13,14}$; and reporting on non-traumatic deaths in the military ${ }^{15-17}$ have all been performed to determine incidence rates of SCA/D. Resulting estimates have varied widely, and whilst the validity of these different attempts has been questioned ${ }^{3,4,18}$, existing data and their quality have not been adequately assessed systematically.

One systematic review has previously been published on the incidence of 'sports related' sudden cardiac death ${ }^{19}$. The review was not pre-registered, did not report its methods according to existing reporting guidelines and assessment of the quality of evidence was not performed, resulting in more questions than answers. The United Kingdom (UK) National Screening Committee has reviewed data on incidence and screening in the young, and produced results recommendations for practice in the UK ${ }^{20}$. We are not aware of a 
medRxiv preprint doi: https://doi.org/10.1101/2020.09.13.20193714; this version posted December 24, 2020. The copyright holder for this preprint (which was not certified by peer review) is the author/funder, who has granted medRxiv a license to display the preprint in perpetuity.

It is made available under a CC-BY-NC-ND 4.0 International license .

comprehensive, pre-registered, peer-reviewed systematic review of the evidence base for the incidence of SCA and SCD in young people regularly participating in regular exercise.

Understanding the existing evidence and it's quality on the epidemiology of SCA and SCD is important when considering professional body recommendations ${ }^{18,21-25}$ for screening athletes with electrocardiograms (ECG) for conditions which may cause such events.

Our objective is to identify publications reporting on the incidence of SCA/D in athletes and military members 40 years of age or younger, assess the quality of the evidence, and synthesize a population level incidence of both SCA and SCD.

\section{Methods}

This review is one portion of a systematic review with two objectives: Identifying the incidence of SCA and SCD in young athletes and military members; and the effect on SCA/D of ECG screening this population ${ }^{26}$. The project was performed according to the Preferred Reporting Items for Systematic Reviews and Meta-Analyses (PRISMA) ${ }^{27}$ guidelines, and was registered on PROSPERO March $18^{\text {th }} 2019$ (CRD42019125560) ${ }^{28}$.

\section{Data Sources and Searches}

The search strategy was designed with a medical librarian (MS) and combined the dual objectives of the project into a single search. Searches were performed in MEDLINE, Embase, Cochrane CENTRAL, Web of Science, BIOSIS, Scopus, SPORT discus, PEDro, between 2/21/19 and 3/1/19, and Clinicaltrials.gov on 7/29/19 for available articles. Relevant review articles and position statements were hand searched for eligible articles ${ }^{5,18,19}$, and articles not identified in 
medRxiv preprint doi: https://doi.org/10.1101/2020.09.13.20193714; this version posted December 24, 2020. The copyright holder for this preprint (which was not certified by peer review) is the author/funder, who has granted medRxiv a license to display the preprint in perpetuity.

It is made available under a CC-BY-NC-ND 4.0 International license .

the online search which reported incidence rates were selected for screening. There was no limitation on language of publication or date. Conference abstracts, published abstracts, and full text publications were included in the review.

\section{Study Selection}

Cohort studies, historically controlled trials, and survey studies which reported incidence of SCA, combining both incidents of SCA and SCD or SCD alone in athletes, or military members age 40 and younger, were eligible for inclusion. Studies which did not report the incidence rate as the primary outcome were included if they reported a rate, or data from which an incidence rate could be calculated. In cases where the study reported events confirmed as SCA or SCD, and suspected cases of SCA or SCD, only the confirmed cases were included in data syntheses. In cases where the authors used a multiplier to address concerns about either cases of SCA/D (numerator), or those eligible for inclusion (denominator), we elected to use the number presented by the authors with the multiplier. This formula was used to calculate either the numerator or denominator when the number of cases or person years was not explicitly detailed: (total number of events/total number person years) $\times 100,000=$ incidence rate per 100,000 person years. In cases where the number of person years in an eligible athlete group is given as a percentage of the total number of person years included in the study, the percentage was used to calculate the number eligible for our study.

Independent dual screening and selection of studies was performed by a team of four reviewers (AL, NP, CM, VL). The primary author $(A L)$ screened all abstracts/titles, and full text 
medRxiv preprint doi: https://doi.org/10.1101/2020.09.13.20193714; this version posted December 24, 2020. The copyright holder for this preprint (which was not certified by peer review) is the author/funder, who has granted medRxiv a license to display the preprint in perpetuity.

It is made available under a CC-BY-NC-ND 4.0 International license .

articles, and was involved in all resolutions of disagreements at each stage of study selection.

$100 \%$ of abstracts and titles were dual screened. $90 \%$ of full text articles were reviewed by two reviewers due to resources and timing. In cases where multiple reports were published on one data set, only the most recent or complete report was included. In cases where different authors used the same databases, the article with the most complete overall database was included. Authors were contacted electronically with questions about screened texts or with requests for eligible data.

\section{Data Extraction and Quality Assessment}

Data extraction, and evaluation of risk of bias (ROB) was performed in all eligible articles by the lead author (AL); 21 of the 40 eligible articles were independently assessed and extracted by a second person (NP, VL, CM), the remaining 19 individually assessed and extracted articles were checked by a senior author (DN). In cases of disagreement, these were resolved by discussion of the two involved parties. ROB was assessed with a validated tool developed to assess prevalence studies ${ }^{29}$, and customized for the purposes of this review. We considered studies done prospectively as the highest level of evidence. Retrospective projects done on databases with largely prospectively collected data were also considered higher quality evidence. Both the ROB tool, and the data extraction guide, are included in the supplemental appendix.

\section{Data Synthesis and Analysis}

The primary outcome was the reported incidence rate of SCA and SCD in competitive athletes, and active duty military members age 40 and under. Competitive athletes were considered 
those participating in athletics of any form or level, including scholastic, recreational, club, collegiate/university level, and professional in or out of season. Active duty military members were included due to the high level of activity that is required of them, the similar age profile, and interest in preventing SCA/D. Pre-specified subgroup analysis was planned by age, sex, race, and by type of sport or military member, as well as level of sport (definitions provided in subgroup analysis in supplementary appendix). Analysis was performed with the Metafor package ${ }^{30}$ in the $R$ statistical software ${ }^{31}$. A random-effects, generalized linear mixed model was used for meta-analysis. Summary findings are presented as events of SCA and SCD per 100,000 person years with $95 \%$ confidence intervals.

Heterogeneity was assessed with $I^{2}$ and $\mathrm{Chi}^{2}$; pre-specified levels of heterogeneity for $I^{2}$ were: $<30 \%$ considered low; $30-70 \%$ considered moderate; and $>70 \%$ was considered high. A p-value of 0.10 or lower for $\mathrm{Chi}^{2}$ statistic was indicated statistical heterogeneity. Assessment of publication bias of the studies included was planned using funnel plots when 10 or more studies were pooled. Sensitivity analyses were planned, if necessary, to evaluate heterogeneity within the results.

\section{Ethical Approval}

Ethical approval was not necessary as only publicly available data was included in this review.

\section{Role of the Funding Source}

No funding was received for this project.

\section{Results}

\section{Study Selection and Characteristics}


medRxiv preprint doi: https://doi.org/10.1101/2020.09.13.20193714; this version posted December 24, 2020. The copyright holder for this preprint (which was not certified by peer review) is the author/funder, who has granted medRxiv a license to display the preprint in perpetuity.

It is made available under a CC-BY-NC-ND 4.0 International license .

After removal of 10,780 duplicates, 20,048 records were identified by the search, and 11

further articles were added by hand search. At the time of screening, we were aware of an important unpublished cohort, which we had elected to include in the final analysis after its publication in $2020^{32}$. 20,060 abstracts were screened and 323 full texts were assessed for inclusion, of which 40 studies met the criteria (Figure 1). The characteristics of the included studies are provided in the data supplement with selected details given in table one.

\section{[FIGURE ONE HERE]}

34 studies included athletes, ranging from youth to professional levels. Articles included were on athletes from the U.S. $(n=16)^{6,9,38-42,13,14,32-37}$, Europe $(n=13)^{10,12,51-53,43-50}$, International $(n=1)^{54}$ Canada $(n=1)^{11}$, Argentina $(n=1)^{55}$, Israel $(n=1)^{8}$, and Australia $(n=1)^{56}$. Five included papers were performed on military members, four in the United States (U.S.), and one in Finland. ${ }^{15-17,57,58}$. A study focusing on firefighters in the U.S. ${ }^{59}$ was also included due to their similarity to military members, and this was grouped with military studies.

$25(61 \%)$ included studies employed retrospective cohort designs; 12 were prospective designs $(30 \%)$ and 3 were surveys (1\%), 2 cross-sectional, and one a recurring annual survey. 11 of the above studies reported extractable data only in men 40,41,43,49,52,56,58,59. 5 studies were included with a large proportion of the included cohort being men ${ }^{15-17,50,57}$. Two studies did not have details about gender included in their methodology but were presumed to be either all men, or a high proportion of men ${ }^{54,55}$. Further details including ages, and levels of sport are included in table one. 
[INSERT TABLE 1 HERE]

\section{Risk of Bias Assessment and Quality Assessment}

$12(30 \%)$ studies were determined to present a low overall ROB $10,11,53,59,12,15-17,32,39,46,50 ; 10$ (25\%) were judged to have moderate risk of bias $6,9,13,35,37,38,48,49,56,58$; and 18 (45\%) were judged to have a high risk of bias $7,8,44,45,47,51,52,54,55,57,14,33,35,36,40-43$. Of the studies considered low ROB, four pertained to military members. One was judged to be prospective in nature ${ }^{15}$, while the remaining three were retrospective reviews of data collected in a prospective fashion ${ }^{16,17,59}$. Similarly, the eight articles on athletes include four studies collected in a prospective nature $1,32,46,50$, with six others considered to be retrospective projects on prospectively collected data ${ }^{10-12,53}$. Further details on ROB judgement on individual studies may be found in table two, with explanations for each study in the supplementary appendix.

[INSERT TABLE 2 HERE]

\section{Study Findings and Data Synthesis}

The studies included presented substantial clinical, statistical, and methodologic heterogeneity. Incidence levels of SCD ranged from 0.02 to 89.05 per 100,000 person years in included studies (Figure 2). Studies reporting SCA had incidence levels ranged from 0.94 to 63.03 per 100,000 person years (Figure 3). 
[INSERT FIGURE 2 HERE]

[INSERT FIGURE 3 HERE]

Meta-analysis was performed only in studies considered to be low ROB. Studies including athletes which were collected at a population level ${ }^{10-12,46,60}$ were combined separately from studies focused on broad groups of competitive athletes under 25 years of age $32,39,50$. The population studies had a point estimate of 0.98 [95\%Cl: $0.62-1.53]$ SCD per 100,000 athlete years with high heterogeneity (Figure 4). Sensitivity analysis removing Corrado, et. al. (2006) which was an outlier, decreased the heterogeneity in the estimate, from $l^{2}$ of $78 \%$ to $0 \%$ and changed the point estimate to 0.90 [95\% Cl: $0.72,1.13]$ SCD per 100,000 . The studies which included only competitive athletes were found to have a point estimate of 1.91 [95\% $\mathrm{Cl}: 0.71$; 5.14] SCD per 100,000 with high heterogeneity (Figure 4). It is notable in this meta-analysis that Peterson, et. al. (2020) only provided extractable detail from high school students on SCD events, while providing detail on university and high school athletes for SCA. Sensitivity analysis removing Malhotra et. al (2018) which included primarily male professional soccer players in England, leaving two studies which included a broad sample of both male and female scholastic and university level athletes did not alter the heterogeneity present, but dropped the point estimate to 1.14 [95\% Cl: $0.59,2.22]$.

We elected not to perform synthesis of the low ROB military studies. The populations of two studies $^{15,16}$ included substantial overlap of included subjects, with very different point estimates 
medRxiv preprint doi: https://doi.org/10.1101/2020.09.13.20193714; this version posted December 24, 2020. The copyright holder for this preprint (which was not certified by peer review) is the author/funder, who has granted medRxiv a license to display the preprint in perpetuity.

It is made available under a CC-BY-NC-ND 4.0 International license .

for SCD $2.91^{15}$ vs $0.98^{16}$ per 100,000 military years; the remaining two studies included substantial clinical heterogeneity in the population, with one ${ }^{17}$ dating back nearly 40 years previous to other included studies, and the other including American firefighters ${ }^{59}$. The point estimates of the low ROB studies in the military range from 0.98 in the most recent publication ${ }^{16}$ to 11.36 SCD per 100,000 person years in the oldest ${ }^{17}$.

[INSERT FIGURE 4 HERE]

Inspection of studies reporting SCD in the moderate and high ROB categories largely are in line with the meta-analyses in low ROB studies. 18 of 28 studies report rates under 2.00 per 100,000 athlete years. The remaining ten studies have estimates which range up to 89.05 per 100,000 athlete years. Three of these are studies with zero events, in which estimates should be taken with caution.

There were only two low ROB studies reporting episodes of SCA, and this data was not synthesized. Landry, et. al. is a retrospective population level study in a region of Ontario, Canada, and reported a rate of 0.94 [95\%Cl: $0.55 ; 1.62]$ SCA per 100,000 athlete years; while Peterson, et. al. (2020) was a prospective study reporting SCA in high school and collegiate athletes in the United States reporting 1.58 [95\%Cl: 1.39; 1.79] SCA per 100,000 athlete years. The moderate and high ROB studies ranged from 1.20 to 63.03 SCA per 100,000 athlete years, with five providing point estimates at less than 2.00 , and the remaining five with estimates between 2.00 and 63.03 per 100,000 person years. 
Synthesis of subgroups was not performed due to the low number of low ROB studies providing subgroup data. Notable findings from low ROB subgroups indicate higher rates of SCA/D in males compared to females ${ }^{32,39}$ with rates over three times as high in males in both cases. Separating athletes by race is difficult based on a lack of uniformity in reporting, but generally indicates elevated rates in black athletes in studies comparing high school and collegiate athletes ${ }^{32,39}$ with white, and in one study Hispanic athletes ${ }^{39}$. These findings are similar to studies in the high ROB category reporting on race ${ }^{34,57}$ which similarly show elevated rates in black military members when compared with white counterparts ${ }^{57}$; and white athletes when compared with non-white athletes ${ }^{34}$. Further narrative detail, as well as forest plot figures with results from individual studies on subgroups including by individual sport, and by level of sport is included in the online supplement.

Visual assessment of the funnel plot (included in supplementary appendix) for publication bias showed asymmetry in the direction of larger studies with larger incidence. This finding is likely related to the heterogeneity present in the included studies.

\section{Discussion}

We believe ours to be the first full systematic review on the subject of sudden cardiac arrest and death in athletes, and in military members. Our analysis has shown a substantial amount of heterogeneity within the published literature on the subject, with most papers showing a 
medRxiv preprint doi: https://doi.org/10.1101/2020.09.13.20193714; this version posted December 24, 2020. The copyright holder for this preprint (which was not certified by peer review) is the author/funder, who has granted medRxiv a license to display the preprint in perpetuity.

It is made available under a CC-BY-NC-ND 4.0 International license .

moderate or high risk of bias. In studies judged to have low ROB, meta-analysis of three published studies in young competitive athletes showed an incidence of SCD to be $1.91[95 \% \mathrm{Cl}$ : $0.71 ; 5.14]$ SCD per 100,000; while five studies including large national or regional populations of athletes was found have an incidence of 0.98 [95\%Cl: $0.62-1.53]$ SCD per 100,000 athlete years. Few low ROB studies reported extractable SCA details. Landry, et. al. (2017) reported on athletes of all levels in a regional population based study in Ontario, Canada. The point estimate was reported as 0.94 [95\% Cl: 0.55; 1.62] per 100,000 athlete years. Peterson, et. al. (2020) reported on high school and university athletes with a point estimate of $1.58[95 \% \mathrm{Cl}$ :

1.39; 1.79$]$ SCA per 100,000 athlete years. Military studies included were not meta-analyzed, but showed a range of estimates of SCD incidence, from 0.98 to 11.36 per 100,000 years.

We believe these findings in high quality studies of athletes confirm the rarity of sudden cardiac arrest and death in athletes. It does appear that the incidence rates in military members may be more frequent than in athletes, but with the heterogeneity present in the estimates, it is difficult to be certain about the point estimate. In both cases, athletes and military, the most extreme estimates come from studies which include populations dating back to the 1970 s in the case of Corrado, et. al. (2006), and into the 1960s in the case of Phillips, et. al. (1986). Including these studies when considering the likely true rates of SCD likely unduly influences results when comparing them to more contemporary reports.

Recent high quality estimates in the United States focused on athletes in high school and university include studies which were conducted in a prospective fashion, or reviewed 
medRxiv preprint doi: https://doi.org/10.1101/2020.09.13.20193714; this version posted December 24, 2020. The copyright holder for this preprint (which was not certified by peer review) is the author/funder, who has granted medRxiv a license to display the preprint in perpetuity.

It is made available under a CC-BY-NC-ND 4.0 International license .

databases which collected information in a prospective manner. In these cases, the estimates of SCD and SCA were under 2 per 100,000 32,39 . In both of these cases, both exertional and nonexertional cases of SCA/D were included in estimates. Criticisms of estimates excluding nonexertional cases have been made in the past ${ }^{5}$, based on the belief that counting on exertional deaths underestimates the risks of SCA/D in the active young population. The same concerns about underestimating risk have been applied to the concept of counting only deaths, while not including arrests in which the subject survives. The estimates provided by these two studies include broad populations of male and female athletes, as well as multi-ethnic studies. They do confirm that the rates of SCA/D in the population of competitive scholastic and university level athletes are greater than other estimates of less than 1 per $100,000^{3}$, therefore, there is not a reason to believe that the rates in these cases are significantly undercounted.

When considering the results of low ROB studies focused on athletes participating in regular practice and competition, the estimate of SCD is slightly higher than in the population based studies including athletes of all levels, including recreational. Of the population based studies, four took place in European countries, and one in Ontario, Canada. The explanations for this difference are likely multifactorial. Of the population based studies, only Corrado, et. al. (2006) includes all deaths in athletes, rather than exertional deaths only. Corrado ${ }^{46}$ however, focuses more on competitive athletes than the remaining four studies ${ }^{10-12,53}$, and as mentioned previously, dates back to the 1970 s for its data collection. It is also true that the population of black athletes is likely to be lower in Europe and Canada, and this must be considered when making comparisons to the United States if the rates in black athletes, as appears to be the 
medRxiv preprint doi: https://doi.org/10.1101/2020.09.13.20193714; this version posted December 24, 2020. The copyright holder for this preprint (which was not certified by peer review) is the author/funder, who has granted medRxiv a license to display the preprint in perpetuity.

It is made available under a CC-BY-NC-ND 4.0 International license .

case, are considerably higher. It is also notable that the ages included in the population level studies extend into the 30s, which one would expect might increase the frequency of SCD related to coronary artery disease, when compared to other conditions causing SCD in the younger athlete ${ }^{32}$. This fact does not appear influential enough to raise the rates of those seen in competitive athletes.

While the overall rate of SCA/D appear relatively low, attention to subgroups of athletes suggests that there are likely areas where rates are consistently much higher. The rates reported by the authors particularly in black males in the sports of basketball and American football are considerably different than their population estimates. Harmon, et. al. (2015) report a rate of 1 SCD in black male basketball players per 4,380 athlete years at the elite university level, while Peterson, et. al. (2020) report a rate of sudden cardiac arrest and death of 1 per 4,810 athlete years in university level athletes at all levels, and 2,087 in athletes at the elite division one level; and reported a rate of 1 per 28,061 in black American football athletes at all levels, and 1 per 18,031 at the division one level. There are four articles reporting outcomes specifically in soccer athletes $49,50,52,54$, and two reporting subgroups of soccer athletes 32,39 . The high quality articles reporting SCD events report rates of 4.22 in university athletes in the United States, and 6.76 in professionals in England per 100,000 athlete years, while the reports of SCA in university athletes in the United States are far lower in the Peterson, et. al. 2020 article, at 1.28 SCA per 100,000 athlete years. The variability in the results of these studies makes it somewhat difficult to interpret, or understand the true risk associated with soccer, in comparison to other sports. 
Applying the data presented in this systematic review confirms the general understanding that occurrence in the young active population for sudden cardiac death appears to be low. This information is further able to inform decisions and recommendations on screening the young active population prior to their participation in sport, or vigorous physical activity such as military service. As is noted in the recent recommendations in the United Kingdom ${ }^{20}$, the rarity in the population of the events make screening and primary prevention a difficult task. It is notable that in the two studies reporting on data collected on cohorts of soccer athletes that had undergone screening ECG, both report rates higher than seen in overall populations, Malhotra, et. al. (2018) reports eight events of SCD for a rate of 6.76 [95\% Cl: $3.38,13.52]$ in a low ROB study; while Berge, et. al. (2018) reports 3 events of SCA for a rate of 63.03 [95\%Cl: 201.33; 195.41] in a study judged to be of moderate ROB related to its use of media sources, and low number of overall athlete years. It is important to note that two of the deaths reported in Malhotra, et. al. were in athletes identified at high risk for SCA/D, who continued to participate against medical advice. While imprecise, and probably not large enough cohorts to settle the question certainly, these two articles give pause to the idea that ECG screening lowers incidence of SCA/D. In addition to data presented over the past decade about the poor sensitivity to identify conditions which put one at risk of SCA/D with history and physical alone ${ }^{61,62}$, the utility of screening to prevent these events remains unproven.

We believe the primary strength of our review lies in the breadth of the search, leading to the ability of this review to draw data from multiple, large population level studies, as well as 
medRxiv preprint doi: https://doi.org/10.1101/2020.09.13.20193714; this version posted December 24, 2020. The copyright holder for this preprint (which was not certified by peer review) is the author/funder, who has granted medRxiv a license to display the preprint in perpetuity.

It is made available under a CC-BY-NC-ND 4.0 International license .

studies focusing specifically on scholastic and college athletes, and studies focusing on military members. We believe this review provides the most up-to-date and precise estimates of population level incidence including athletes of all types, as well as incidence in competitive athletes. We also believe narrative review of subgroups adds to the overall knowledge base about those with high and low risk levels. This review also provides an assessment of the level of evidence published on the subject of the incidence of SCA/D.

Limitations of our review include substantial clinical and statistical heterogeneity in the published data, as well as the overall low proportion of data judged to have low ROB. Many of the studies included only males, and/or single sports, and were judged to be at moderate or high risk of bias, tempering the robustness of their findings. Most of the data included in this review is drawn from studies in Europe and the United States, potentially limiting the applicability of our findings outside of these regions. Due to available resources and timing, not all included studies were double extracted or assessed for risk of bias.

\section{Conclusion}

This systematic review provides the most comprehensive review of the available data on sudden cardiac arrest and death in active populations under the age of 40 . Our estimate of the incidence of SCD in high quality studies shows SCD to be a rare occurrence in both population level studies including all levels of athletes, 0.98 [95\%Cl: 0.62-1.53] SCD per 100,000 athlete years, and focused studies evaluating young competitive athletes between the ages of 14 and 25, $1.91[95 \% \mathrm{Cl}: 0.71 ; 5.14]$ SCD per 100,000 . Our evaluation of the published literature 
medRxiv preprint doi: https://doi.org/10.1101/2020.09.13.20193714; this version posted December 24, 2020. The copyright holder for this preprint (which was not certified by peer review) is the author/funder, who has granted medRxiv a license to display the preprint in perpetuity. It is made available under a CC-BY-NC-ND 4.0 International license .

suggests higher incidence of both SCD and SCA with male sex, black athletes, and potentially in the military compared with athletic involvement. We believe that the estimates presented here for broad populations of competitive athletes are not likely to be changed by further publications. We do believe that population based studies may be improved upon by including events at all times, in comparison to events which occur only with exertion. As has been suggested previously ${ }^{63}$, a uniform reporting system of sudden deaths in the young active population would benefit the understanding of this condition, and advance a more reliable understanding of the incidence of both sudden cardiac arrest and death. 
medRxiv preprint doi: https://doi.org/10.1101/2020.09.13.20193714; this version posted December $24,2020$. The copyright holder for this preprint (which was not certified by peer review) is the author/funder, who has granted medRxiv a license to display the preprint in perpetuity.

It is made available under a CC-BY-NC-ND 4.0 International license .

\section{References}

1. Harmon KG, Asif IM, Maleszewski J, et al. Incidence, Etiology, and Comparative Frequency of Sudden Cardiac Death in NCAA Athletes: A Decade in Review. Circulation. 2015;132(1):10-19. doi:10.1007/s10549-015-3663-1.Progestin

2. Drezner JA, O'Connor FG, Harmon KG, et al. AMSSM Position Statement on Cardiovascular Preparticipation Screening in Athletes: Current Evidence, Knowledge Gaps, Recommendations and Future Directions. Curr Sports Med Rep. 2016;15(5):359375.

3. Van Brabandt H, Desomer A, Gerkens S, Neyt M. Harms and benefits of screening young people to prevent sudden cardiac death. BMJ. 2016;353(April):1-5. doi:10.1136/bmj.i1156

4. Drezner JA, Harmon KG, Asif IM, Marek JC. Why cardiovascular screening in young athletes can save lives: a critical review. Br J Sports Med. 2016;50(22):1376-1378.

5. Harmon KG, Drezner JA, Wilson MG, Sharma S. Incidence of sudden cardiac death in athletes: A state-of-the-art review. Br J Sports Med. 2014;48(15):1185-1192.

doi:10.1136/bjsports-2014-093872

6. Drezner JA, Rogers KJ, Zimmer RR, Sennett BJ. Use of automated external defibrillators at NCAA Division I universities. Med Sci Sport Exerc. 2005;37(9 PG-1487-92):1487-1492.

7. Drezner JA, Rao AL, Heistand J, Bloomingdale MK, Harmon KG. Effectiveness of emergency response planning for sudden cardiac arrest in United States high schools with automated external defibrillators. Circulation. 2009;120(6 PG-518-25):518-525.

8. Steinvil A, Chundadze T, Zeltser D, et al. Mandatory electrocardiographic screening of 
medRxiv preprint doi: https://doi.org/10.1101/2020.09.13.20193714; this version posted December $24,2020$. The copyright holder for this preprint (which was not certified by peer review) is the author/funder, who has granted medRxiv a license to display the preprint in perpetuity.

It is made available under a CC-BY-NC-ND 4.0 International license .

athletes to reduce their risk for sudden death proven fact or wishful thinking? J Am Coll Cardiol. 2011;57(11):1291-1296.

9. Harmon KG, Asif IM, Maleszewski JJ, et al. Incidence and Etiology of Sudden Cardiac Arrest and Death in High School Athletes in the United States. Mayo Clin Proc. 2016;91(11 PG-1493-1502):1493-1502.

10. Marijon E, Tafflet M, Celermajer DS, et al. Sports-related sudden death in the general population. Circulation. 2011;124(6 PG-672-81):672-681.

11. Landry CH, Allan KS, Connelly KA, Cunningham K, Morrison L, Dorian P. Sudden Cardiac Arrest during Participation in Competitive Sports. N Engl J Med. 2017;377(20):1943-1953. doi:10.1056/NEJMoa1615710

12. Holst AG, Winkel BG, Theilade J, et al. Incidence and etiology of sports-related sudden cardiac death in Denmark--implications for preparticipation screening. Hear Rhythm. 2010;7(10 PG-1365-71):1365-1371.

13. Maron BJ, Gohman TE, Aeppli D. Prevalence of sudden cardiac death during competitive sports activities in Minnesota high school athletes. J Am Coll Cardiol. 1998;32(7 PG-18814):1881-1884.

14. Roberts WO, Stovitz SD. Incidence of sudden cardiac death in Minnesota high school athletes 1993-2012 screened with a standardized pre-participation evaluation. J Am Coll Cardiol. 2013;62(14):1298-1301.

15. Eckart RE, Shry EA, Burke AP, et al. Sudden death in young adults: an autopsy-based series of a population undergoing active surveillance. J Am Coll Cardiol. 2011;58(12 PG1254-61):1254-1261. 
medRxiv preprint doi: https://doi.org/10.1101/2020.09.13.20193714; this version posted December $24,2020$. The copyright holder for this preprint (which was not certified by peer review) is the author/funder, who has granted medRxiv a license to display the preprint in perpetuity.

It is made available under a CC-BY-NC-ND 4.0 International license .

16. Smallman DP, Webber BJ, Mazuchowski EL, Scher Al, Jones SO, Cantrell JA. Sudden cardiac death associated with physical exertion in the US military, 2005-2010. Br J Sports Med. 2016;50(2 PG-118-23):118-123.

17. Phillips M, Robinowitz M, Higgins JR. Sudden cardiac death in Air Force recruits. A 20year review. J Am Med Assoc. 1986;256(19 PG-2696-2699):2696-2699.

http://resolver.ebscohost.com/openurl?sid=OVID:embase\&id=pmid:3773175\&id=doi:10. 1001\%2Fjama.256.19.2696\&issn=0098-

7484\&isbn=\&volume=256\&issue=19\&spage=2696\&date=1986\&title=Journal+of+the + Am erican+Medical+Association\&atitle=Sudden+cardiac+death+in+Air+Forc.

18. Drezner JA, O'Connor FG, Harmon KG, et al. AMSSM Position Statement on Cardiovascular Preparticipation Screening in Athletes: Current evidence, knowledge gaps, recommendations and future directions.[Erratum appears in Br J Sports Med. 2018 Mar 6;:; PMID: 29510974]. Br J Sports Med. 2017;51(3):153-167.

19. Mohananey D, Masri A, Desai RM, et al. Global Incidence of Sports-Related Sudden Cardiac Death. J Am Coll Cardiol. 2017;69(21):2672-2673. doi:10.1016/j.jacc.2017.03.564

20. Couper AK, Poole K, Bradlow W, Field R, Perkins GD, Royle P. Screening for cardiac conditions associated with sudden cardiac death in the young External review against programme appraisal criteria for the UK National Screening Committee Version : FINAL About the UK National Screening Committee ( UK NSC ). 2019;(October).

21. Corrado D, Pelliccia A, Bjornstad HH, et al. Cardiovascular pre-participation screening of young competitive athletes for prevention of sudden death: proposal for a common 
medRxiv preprint doi: https://doi.org/10.1101/2020.09.13.20193714; this version posted December $24,2020$. The copyright holder for this preprint (which was not certified by peer review) is the author/funder, who has granted medRxiv a license to display the preprint in perpetuity.

It is made available under a CC-BY-NC-ND 4.0 International license .

European protocol. Consensus Statement of the Study Group of Sport Cardiology of the Working Group of Cardiac Rehabilitation and. Eur Heart J. 2005;26(5):516-524.

22. Ingersoll CD. The periodic health evaluation of elite athletes: A consensus statement from the international olympic committee. J Athl Train. 2009;44(5):453.

doi:10.4085/1062-6050-44.5.453

23. Exeter D, Kuah D, Carbon R, Shawdon A, Bolzonello D. Australasian College of Sport and Exercise Physicians (ACSEP) Position Statement on Pre- Participation Cardiac Evaluation in Young Athletes. https://www.acsep.org.au. Published 2018.

24. Hainline B, Drezner J, Baggish A, et al. Interassociation consensus statement on cardiovascular care of college student-athletes. J Athl Train. 2016;51(4):344-357. doi:10.4085/j.jacc.2016.03.527

25. Maron BJ, Levine BD, Washington RL, et al. Eligibility and Disqualification Recommendations for Competitive Athletes With Cardiovascular Abnormalities: Task Force 2: Preparticipation Screening for Cardiovascular Disease in Competitive Athletes: A Scientific Statement From the American Heart Associ. Circulation. 2015;132(22):e267-72.

26. Lear A, Patel N, Mullen C, et al. Screening electrocardiogram in young athletes and military members: systematic review and meta-analysis. Unpublished. medRxiv Preprint 2020. https://doi.org/10.1101/2020.09.13.20193706.

27. PRISMA. http://prisma-statement.org. Published 2009. Accessed July 16, 2019.

28. Lear A. A systematic review to determine the rate of sudden cardiac arrest and death in athletes, and to determine the benefits and harms of the electrocardiogram screening of athletes. PROSPERO. 
http://www.crd.york.ac.uk/PROSPERO/display_record.php?ID=CRD42019125560.

Published 2019.

29. Hoy D, Brooks $P$, Woolf $A$, et al. Assessing risk of bias in prevalence studies: Modification of an existing tool and evidence of interrater agreement. J Clin Epidemiol.

2012;65(9):934-939. doi:10.1016/j.jclinepi.2011.11.014

30. Viechtbauer W. Conducting meta-analyses in R with the metafor package. J Stat Softw. 2010;36(3):1-48.

31. R Core Team. R: A language and environment for statistical computing. 2013.

http://www.r-project.org/.

32. Peterson DF, Kucera K, Thomas LC, et al. Aetiology and incidence of sudden cardiac arrest and death in young competitive athletes in the USA: A 4-year prospective study. Br J

Sports Med. 2020:1-9. doi:10.1136/bjsports-2020-102666

33. Endres BD, Kerr ZY, Stearns RL, et al. Epidemiology of Sudden Death in Organized Youth Sports in the United States, 2007-2015. J Athl Train. 2019;54(4 PG-349-355):349-355. doi:10.4085/1062-6050-358-18

34. Maron BJ, Haas TS, Ahluwalia A, Murphy CJ, Garberich RF. Demographics and Epidemiology of Sudden Deaths in Young Competitive Athletes: From the United States National Registry. Am J Med. 2016;129(11 PG-1170-1177):1170-1177.

35. Maron BJ, Haas TS, Duncanson ER, Garberich RF, Baker AM, Mackey-Bojack S.

Comparison of the Frequency of Sudden Cardiovascular Deaths in Young Competitive Athletes Versus Nonathletes: Should We Really Screen Only Athletes? Am J Cardiol. 2016;117(8):1339-1341. 
medRxiv preprint doi: https://doi.org/10.1101/2020.09.13.20193714; this version posted December $24,2020$. The copyright holder for this preprint (which was not certified by peer review) is the author/funder, who has granted medRxiv a license to display the preprint in perpetuity.

It is made available under a CC-BY-NC-ND 4.0 International license .

36. Fuller CM, McNulty CM, Spring DA, et al. Prospective screening of 5,615 high school athletes for risk of sudden cardiac death. Med Sci Sport Exerc. 1997;29(9):1131-1138.

37. Maron BJ, Haas TS, Ahluwalia A, Rutten-Ramos SC. Incidence of cardiovascular sudden deaths in Minnesota high school athletes. Hear Rhythm. 2013;10(3):374-377.

38. Toresdahl BG, Rao AL, Harmon KG, Drezner JA. Incidence of sudden cardiac arrest in high school student athletes on school campus. Hear Rhythm. 2014;11(7 PG-1190-4):11901194.

39. Harmon KG, Asif IM, Maleszewski JJ, et al. Incidence, Cause, and Comparative Frequency of Sudden Cardiac Death in National Collegiate Athletic Association Athletes: A Decade in Review. Circulation. 2015;132(1 PG-10-9):10-19.

40. Kucera KL, Klossner D, Colgate B, Cantu RC. Annual Survey of Football Injury Research. Chapel Hill, NC: University of North Carolina, Chapel Hill; 2018. NS -.

41. Boden BP, Breit I, Beachler JA, Williams A, Mueller FO. Fatalities in high school and college football players. Am J Sports Med. 2013;41(5 PG-1108-16):1108-1116.

42. Maron BJ, Doerer JJ, Haas TS, Estes NA, Hodges JS, Link MS. Commotio cordis and the epidemiology of sudden death in competitive lacrosse. Pediatrics. 2009;124(3 PG-96671):966-971.

43. Solberg EE, Gjertsen F, Haugstad E, Kolsrud L. Sudden death in sports among young adults in Norway. Eur J Cardiovasc Prev Rehabil. 2010;17(3 PG-337-41):337-341.

44. Assanelli D, Marconi M, Cazzamalli L, et al. Sudden death in seven young athletes during sports activity. [Italian]. Int J Sport Cardiol. 1995;4(1 PG-25-29):25-29.

45. Chevalier L, Hajjar M, Douard H, et al. Sports-related acute cardiovascular events in a 
medRxiv preprint doi: https://doi.org/10.1101/2020.09.13.20193714; this version posted December $24,2020$. The copyright holder for this preprint (which was not certified by peer review) is the author/funder, who has granted medRxiv a license to display the preprint in perpetuity. It is made available under a CC-BY-NC-ND 4.0 International license .

general population: a French prospective study. Eur J Cardiovasc Prev Rehabil. 2009;16(3 PG-365-70):365-370.

46. Corrado D, Basso C, Pavei A, Michieli P, Schiavon M, Thiene G. Trends in sudden cardiovascular death in young competitive athletes after implementation of a preparticipation screening program. JAMA. 2006;296(13):1593-1601.

47. Durakovic Z, Durakovic MM, Skavic J. Sudden cardiac death due to physical exercise in Croatia in a 27-year period. Med Sci. 2012;37(PG-19-51):19-51. NS - Durakovic 2012.

48. Grani C, Chappex N, Fracasso T, et al. Sports-related sudden cardiac death in Switzerland classified by static and dynamic components of exercise. Eur J Prev Cardiol. 2016;23(11 PG-1228-36):1228-1236.

49. Berge HM, Andersen TE, Bahr R. Cardiovascular incidents in male professional football players with negative preparticipation cardiac screening results: an 8-year follow-up. $\mathrm{Br} \mathrm{J}$ Sports Med. October 2018:bjsports-2018-099845. doi:10.1136/bjsports-2018-099845

50. Malhotra A, Dhutia H, Finocchiaro G, et al. Outcomes of Cardiac Screening in Adolescent Soccer Players. N Engl J Med. 2018;379(6):524-534.

51. Jordaens L, Van Lierde J, Van De Velde D, De Backer G. Competitive cyclging in Belgium is associated with an increased risk of sudden death. Pacing Clin Electrophysiol. 1996;19(4 PG-602-603):602-603.

52. Biasco L, Cristoforetti Y, Castagno D, et al. Clinical, electrocardiographic, echocardiographic characteristics and long-term follow-up of elite soccer players with Jpoint elevation. Circ Arrhythmia Electrophysiol. 2013;6(6):1178-1184.

53. Risgaard B, Winkel BG, Jabbari R, et al. Sports-related sudden cardiac death in a 
medRxiv preprint doi: https://doi.org/10.1101/2020.09.13.20193714; this version posted December $24,2020$. The copyright holder for this preprint (which was not certified by peer review) is the author/funder, who has granted medRxiv a license to display the preprint in perpetuity.

It is made available under a CC-BY-NC-ND 4.0 International license .

competitive and a noncompetitive athlete population aged 12 to 49 years: data from an unselected nationwide study in Denmark. Hear Rhythm. 2014;11(10 PG-1673-81):16731681.

54. Santos-Lozano A, Martin-Hernandez J, Baladron C, et al. Sudden Cardiac Death in Professional Soccer Players. J Am Coll Cardiol. 2017;70(11 PG-1420-1421):1420-1421. doi:10.1016/j.jacc.2017.07.738

55. Maurice MF, Di Tommaso F, Barros Pertuz MC, Mendoza WA, Spagnuolo D, Lucas V. Sudden cardiac death in rugby clubs. Rev Argent Cardiol. 2018;86(1 PG-40-44):40-44.

56. Young MC, Fricker PA, Thomson NJ, Lee KA. Sudden death due to ischaemic heart disease in young aboriginal sportsmen in the Northern Territory, 1982-1996. Med J Aust. 1999;170(9 PG-425-8):425-428.

57. Eckart RE, Scoville S, Campbell C, et al. Sudden death in young adults : A 25-year review of autopsies in Annals of Internal Medicine Article. Ann Intern Med. 2004;141(11).

58. Koskenvuo K. Sudden deaths among Finnish conscripts. Br Med J. 1976;2(6049 PG-14135):1413-1415.

59. Farioli A, Christophi CA, Quarta CC, Kales SN. Incidence of Sudden Cardiac Death in a Young Active Population. J Am Heart Assoc. 2015;4 (6).

60. Sadjadieh G, Jabbari R, Risgaard B, et al. Nationwide (Denmark) study of symptoms preceding sudden death due to arrhythmogenic right ventricular cardiomyopathy. Am J Cardiol. 2014;113(7):1250-1254.

61. Fudge J, Harmon KG, Owens DS, et al. Cardiovascular screening in adolescents and young adults: A prospective study comparing the Pre-participation Physical Evaluation 
medRxiv preprint doi: https://doi.org/10.1101/2020.09.13.20193714; this version posted December 24, 2020. The copyright holder for this preprint (which was not certified by peer review) is the author/funder, who has granted medRxiv a license to display the preprint in perpetuity. It is made available under a CC-BY-NC-ND 4.0 International license .

Monograph 4th Edition and ECG. Br J Sports Med. 2014;48(15):1172-1178.

doi:10.1136/bjsports-2014-093840

62. Williams EA, Pelto HF, Toresdahl BG, et al. Performance of the American Heart Association (AHA) 14-Point Evaluation Versus Electrocardiography for the Cardiovascular Screening of High School Athletes: A Prospective Study. J Am Heart Assoc. 2019;8(14):19. doi:10.1161/JAHA.119.012235

63. Solberg EE, Borjesson M, Sharma S, et al. Sudden cardiac arrest in sports - Need for uniform registration: A Position Paper from the Sport Cardiology Section of the European Association for Cardiovascular Prevention and Rehabilitation. Eur J Prev Cardiol. 2016;23(6):657-667. doi:10.1177/2047487315599891 
medRxiv preprint doi: https://doi.org/10.1101/2020.09.13.20193714; this version posted December 24, 2020. The copyright holder for this preprint (which was not certified by peer review) is the author/funder, who has granted medRxiv a license to display the preprint in perpetuity.

It is made available under a CC-BY-NC-ND 4.0 International license .

\section{Figures/Tables}


medRxiv preprint doi: https://doi.org/10.1101/2020.09.13.20193714; this version posted December 24, 2020. The copyright holder for this preprint (which was not certified by peer review) is the author/funder, who has granted medRxiv a license to display the preprint in perpetuity.

It is made available under a CC-BY-NC-ND 4.0 International license .

PRISMA Flow Diagram

27

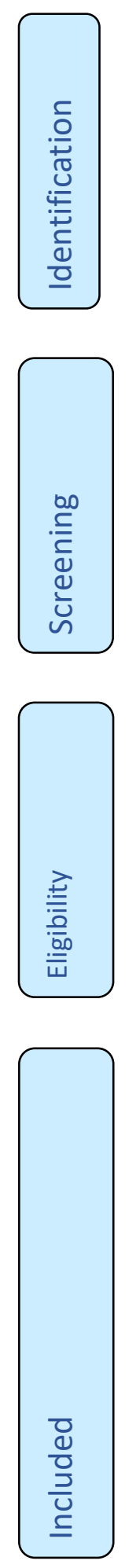

Records identified through database searching ( $n=30856$ as 30828 studies)
Additional records identified through other sources

$(n=12)$
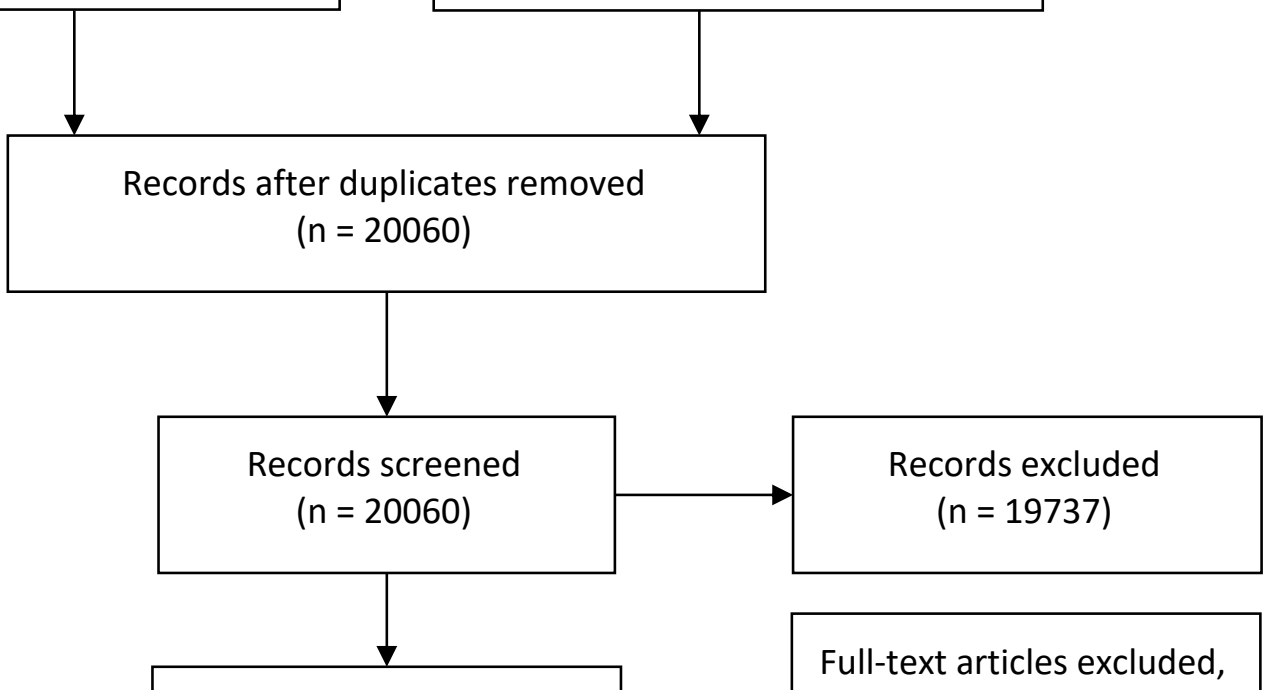

Full-text articles excluded,

Full-text articles assessed for eligibility with reasons

$$
(n=283)
$$

$(n=323)$

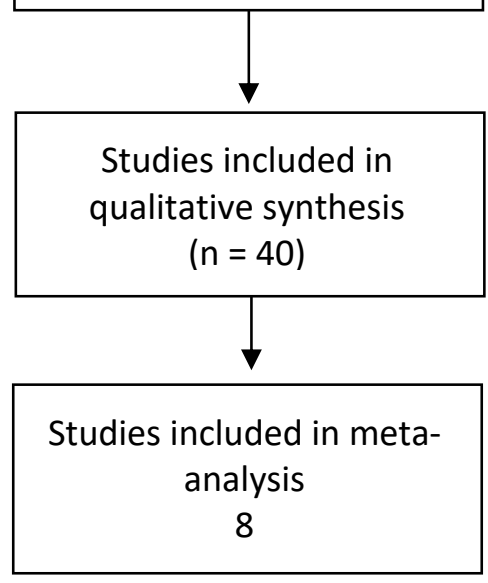

94 Wrong study design 61 Epidemiology with no denominator 33 ECG cohort with no comparator 30 Duplicate 20 Wrong patient population 19 Review article 16 Same cohort published in other place 8 Erroneous citationsarticle not found 1 Article unable to be located 1 Ineligible outcomes 


\begin{tabular}{|c|c|c|c|c|c|c|c|c|c|c|c|c|}
\hline $\begin{array}{l}\text { 1st Author } \\
\text { and year of } \\
\text { publication }\end{array}$ & Methodology & $\begin{array}{l}\text { Open } \\
\text { vs } \\
\text { closed } \\
\text { cohort }\end{array}$ & $\begin{array}{l}\text { Exertional } \\
\text { only or all } \\
\text { cardiac } \\
\text { deaths }\end{array}$ & $\begin{array}{l}\text { Method of case } \\
\text { identification }\end{array}$ & $\begin{array}{l}\text { SCA or } \\
\text { SCD } \\
\text { Reported }\end{array}$ & $\begin{array}{l}\text { Category } \\
\text { of sport or } \\
\text { activity }\end{array}$ & $\begin{array}{l}\text { Level of } \\
\text { sport or } \\
\text { activity }\end{array}$ & $\begin{array}{l}\text { ECG } \\
\text { screened }\end{array}$ & Ages (yrs) & Sex & $\begin{array}{l}\text { Study } \\
\text { Length } \\
\text { (yrs) }\end{array}$ & ROB \\
\hline Phillips 1986 & $\begin{array}{l}\text { Retrospective } \\
\text { Cohort }\end{array}$ & Known & Exertional & Autopsy reports & SCD only & Military & Military & No & $17-28$ & $M \& F$ & 6 & Low \\
\hline Corrado 2006 & $\begin{array}{l}\text { Prospective } \\
\text { Cohort }\end{array}$ & Open & All & $\begin{array}{l}\text { Combined media } \\
\text { reports/autopsy and } \\
\text { medical records }\end{array}$ & SCD only & Multiple & Competitive & Portion & $12-35$ & $M \& F$ & 24 & Low \\
\hline Holst 2010 & $\begin{array}{l}\text { Retrospective } \\
\text { Cohort }\end{array}$ & Open & Exertional & Death certificate & SCD only & Soccer & Competitive & $\begin{array}{l}\text { Not } \\
\text { described }\end{array}$ & $12-35$ & $M \& F$ & 12 & Low \\
\hline Eckart 2011 & $\begin{array}{l}\text { Prospective } \\
\text { Cohort }\end{array}$ & Known & All & $\begin{array}{l}\text { Combined } \\
\text { autopsy/other official } \\
\text { record such as } \\
\text { medical, military, } \\
\text { athletic body }\end{array}$ & SCD only & Military & Military & No & $18-34$ & $M \& F$ & 1 & Low \\
\hline Marijon 2011 & $\begin{array}{l}\text { Retrospective } \\
\text { Cohort }\end{array}$ & Open & Exertional & $\begin{array}{l}\text { Combined media } \\
\text { reports/autopsy and } \\
\text { medical records }\end{array}$ & $\begin{array}{l}\text { SCD (SCA } \\
\text { included in } \\
\text { SCD count) }\end{array}$ & Multiple & Competitive & No & $10-35$ & $M \& F$ & 26 & Low \\
\hline $\begin{array}{l}\text { Risgaard } \\
2014\end{array}$ & $\begin{array}{l}\text { Retrospective } \\
\text { Cohort }\end{array}$ & Open & Exertional & $\begin{array}{l}\text { Combined media } \\
\text { reports/autopsy and } \\
\text { medical records }\end{array}$ & SCD only & Multiple & Competitive & No & $12-35$ & $M \& F$ & 9 & Low \\
\hline Farioli 2015 & $\begin{array}{l}\text { Retrospective } \\
\text { Cohort }\end{array}$ & Open & All & $\begin{array}{l}\text { Combined } \\
\text { autopsy/other official } \\
\text { record such as } \\
\text { medical, military, } \\
\text { athletic body }\end{array}$ & SCD only & Military & Military & No & $18-34$ & $M$ & 25 & Low \\
\hline Harmon 2015 & $\begin{array}{l}\text { Prospective } \\
\text { Cohort }\end{array}$ & Open & All & $\begin{array}{l}\text { Combined media } \\
\text { reports/autopsy and } \\
\text { medical records }\end{array}$ & SCD only & Multiple & University & $\begin{array}{l}\text { Not } \\
\text { described }\end{array}$ & $17-24$ & $M \& F$ & 26 & Low \\
\hline $\begin{array}{l}\text { Smallman } \\
2016\end{array}$ & $\begin{array}{l}\text { Retrospective } \\
\text { Cohort }\end{array}$ & Known & Exertional & $\begin{array}{l}\text { Combined } \\
\text { autopsy/other official } \\
\text { record such as } \\
\text { medical, military, } \\
\text { athletic body }\end{array}$ & SCD only & Military & Military & No & $<35$ & $M \& F$ & 10 & Low \\
\hline Landry 2017 & $\begin{array}{l}\text { Retrospective } \\
\text { Cohort }\end{array}$ & Open & Exertional & $\begin{array}{l}\text { Combined } \\
\text { autopsy/other official } \\
\text { record such as } \\
\text { medical, military, } \\
\text { athletic body }\end{array}$ & $\begin{array}{l}\text { SCA and } \\
\text { SCD }\end{array}$ & Multiple & Multiple & $\begin{array}{l}\text { Not } \\
\text { described }\end{array}$ & $12-35$ & $M \& F$ & 32 & Low \\
\hline Malhotra 2018 & $\begin{array}{l}\text { Prospective } \\
\text { Cohort }\end{array}$ & Known & All & $\begin{array}{l}\text { Combined } \\
\text { autopsy/other official } \\
\text { record such as } \\
\text { medical, military, } \\
\text { athletic body }\end{array}$ & SCD only & Soccer & Elite & Yes & $\begin{array}{l}15-17 \text { at time } \\
\text { of screen }\end{array}$ & $M \& F$ & 15 & Low \\
\hline $\begin{array}{l}\text { Peterson } \\
2020\end{array}$ & $\begin{array}{l}\text { Prospective } \\
\text { Cohort }\end{array}$ & Open & All & $\begin{array}{l}\text { Combined } \\
\text { autopsy/other official }\end{array}$ & $\begin{array}{l}\text { SCA and } \\
\text { SCD }\end{array}$ & Multiple & Multiple & $\begin{array}{l}\text { Not } \\
\text { described }\end{array}$ & $11-29$ & $M \& F$ & 4 & Low \\
\hline
\end{tabular}




\begin{tabular}{|c|c|c|c|c|c|c|c|c|c|c|c|c|}
\hline & & & & $\begin{array}{l}\text { record such as } \\
\text { medical, military, } \\
\text { athletic body }\end{array}$ & & & & & & & & \\
\hline $\begin{array}{l}\text { Koskenvuo } \\
1976\end{array}$ & $\begin{array}{l}\text { Retrospective } \\
\text { Cohort }\end{array}$ & Known & $\begin{array}{l}\text { Not } \\
\text { described }\end{array}$ & $\begin{array}{l}\text { Combined } \\
\text { autopsy/other official } \\
\text { record such as } \\
\text { medical, military, } \\
\text { athletic body }\end{array}$ & SCD only & Military & Military & No & $18-24$ & $M$ & 6 & Moderate \\
\hline Maron 1998 & $\begin{array}{l}\text { Retrospective } \\
\text { Cohort }\end{array}$ & Open & Exertional & Autopsy reports & SCD only & Multiple & Scholastic & No & $13-19$ & $M \& F$ & 1 & Moderate \\
\hline Young 1999 & $\begin{array}{l}\text { Retrospective } \\
\text { Cohort }\end{array}$ & Open & Exertional & Autopsy reports & SCD only & $\begin{array}{l}\text { Australian } \\
\text { football }\end{array}$ & Competitive & No & $15-37$ & $M$ & 3 & Moderate \\
\hline Drezner 2005 & Survey & Open & $\begin{array}{l}\text { Not } \\
\text { described }\end{array}$ & $\begin{array}{l}\text { Facility event report } \\
\text { (ex: school records) }\end{array}$ & $\begin{array}{l}\text { SCA and } \\
\text { SCD }\end{array}$ & Multiple & Elite & $\begin{array}{l}\text { Not } \\
\text { described }\end{array}$ & $17-24$ & $M \& F$ & 0.5 & Moderate \\
\hline Maron 2013 & $\begin{array}{l}\text { Retrospective } \\
\text { Cohort }\end{array}$ & Open & All & $\begin{array}{l}\text { Combined media } \\
\text { reports/autopsy and } \\
\text { medical records }\end{array}$ & SCD only & Multiple & Scholastic & No & $12-18$ & $M \& F$ & 3 & Moderate \\
\hline $\begin{array}{l}\text { Toresdahl } \\
2014 \\
\end{array}$ & $\begin{array}{l}\text { Prospective } \\
\text { Cohort }\end{array}$ & Known & All & $\begin{array}{l}\text { Interview } \\
\text { family/eyewitness }\end{array}$ & $\begin{array}{l}\text { SCA and } \\
\text { SCD }\end{array}$ & Multiple & Scholastic & No & $14-19$ & $M \& F$ & 11 & Moderate \\
\hline Harmon 2016 & $\begin{array}{l}\text { Prospective } \\
\text { Cohort }\end{array}$ & Open & All & Media reports & $\begin{array}{l}\text { SCA and } \\
\text { SCD }\end{array}$ & Multiple & Scholastic & No & $14-19$ & $M \& F$ & 10 & Moderate \\
\hline Grani 2016 & $\begin{array}{l}\text { Retrospective } \\
\text { Cohort }\end{array}$ & Open & Exertional & Autopsy reports & SCD only & Multiple & Multiple & Portion & $10-39$ & $M$ & 7 & Moderate \\
\hline Maron 2016a & $\begin{array}{l}\text { Retrospective } \\
\text { Cohort }\end{array}$ & Open & All & Autopsy reports & SCD only & Multiple & Multiple & No & $14-23$ & $M \& F$ & 20 & Moderate \\
\hline Berge 2018 & $\begin{array}{l}\text { Retrospective } \\
\text { Cohort }\end{array}$ & Known & All & Media reports & $\begin{array}{l}\text { SCA and } \\
\text { SCD }\end{array}$ & Soccer & Elite & Yes & $18-40$ & $M$ & 15 & Moderate \\
\hline $\begin{array}{l}\text { Assanelli } \\
1995\end{array}$ & $\begin{array}{l}\text { Prospective } \\
\text { Cohort }\end{array}$ & $\begin{array}{l}\text { Not } \\
\text { Describe } \\
d\end{array}$ & $\begin{array}{l}\text { Not } \\
\text { described }\end{array}$ & Medical records & $\begin{array}{l}\text { SCA and } \\
\text { SCD }\end{array}$ & Multiple & Multiple & Yes & unclear & $M \& F$ & 5 & High \\
\hline $\begin{array}{l}\text { Jordaens } \\
1996\end{array}$ & $\begin{array}{l}\text { Retrospective } \\
\text { Cohort }\end{array}$ & Open & $\begin{array}{l}\text { Not } \\
\text { described }\end{array}$ & Media reports & SCD only & Cycling & Elite & $\begin{array}{l}\text { Not } \\
\text { described }\end{array}$ & unknown & $M \& F$ & 2 & High \\
\hline Fuller 1997 & $\begin{array}{l}\text { Prospective } \\
\text { Cohort }\end{array}$ & Known & $\begin{array}{l}\text { Not } \\
\text { described }\end{array}$ & Not reported & $\begin{array}{l}\text { SCA and } \\
\text { SCD }\end{array}$ & Multiple & Scholastic & Yes & $<20$ & $M \& F$ & 8 & High \\
\hline Eckart 2004 & $\begin{array}{l}\text { Retrospective } \\
\text { Cohort }\end{array}$ & Known & All & $\begin{array}{l}\text { Combined } \\
\text { autopsy/other official } \\
\text { record such as } \\
\text { medical, military, } \\
\text { athletic body }\end{array}$ & SCD only & Military & Military & No & $17-35$ & $M \& F$ & 3.3 & High \\
\hline $\begin{array}{l}\text { Chevalier } \\
2009\end{array}$ & $\begin{array}{l}\text { Prospective } \\
\text { Cohort }\end{array}$ & Open & Exertional & Medical records & SCD only & Multiple & Multiple & No & $<35$ & $M \& F$ & 21 & High \\
\hline Drezner 2009 & Survey & Open & $\begin{array}{l}\text { Not } \\
\text { described }\end{array}$ & $\begin{array}{l}\text { Facility event report } \\
\text { (ex: school records) }\end{array}$ & $\begin{array}{l}\text { SCA and } \\
\text { SCD }\end{array}$ & Multiple & Scholastic & No & $14-19$ & $M \& F$ & 10 & High \\
\hline Maron 2009 & $\begin{array}{l}\text { Retrospective } \\
\text { Cohort }\end{array}$ & Open & All & $\begin{array}{l}\text { Combined media } \\
\text { reports/autopsy and } \\
\text { medical records }\end{array}$ & $\begin{array}{l}\text { SCA and } \\
\text { SCD }\end{array}$ & Lacrosse & Competitive & No & $14-23$ & $M \& F$ & 32 & High \\
\hline
\end{tabular}




\begin{tabular}{|c|c|c|c|c|c|c|c|c|c|c|c|c|}
\hline Solberg 2010 & $\begin{array}{l}\text { Retrospective } \\
\text { Cohort }\end{array}$ & Open & Exertional & $\begin{array}{l}\text { Combined } \\
\text { autopsy/other official } \\
\text { record such as } \\
\text { medical, military, } \\
\text { athletic body }\end{array}$ & SCD only & Multiple & Multiple & No & $15-34$ & $M$ & 10 & High \\
\hline Steinvil 2011 & $\begin{array}{l}\text { Retrospective } \\
\text { Cohort }\end{array}$ & Open & $\begin{array}{l}\text { Not } \\
\text { described }\end{array}$ & Media reports & $\begin{array}{l}\text { SCA and } \\
\text { SCD }\end{array}$ & Multiple & Competitive & Portion & unclear & $M \& F$ & 15 & High \\
\hline $\begin{array}{l}\text { Durakovic } \\
2012\end{array}$ & $\begin{array}{l}\text { Retrospective } \\
\text { Cohort }\end{array}$ & Open & $\begin{array}{l}\text { Not } \\
\text { described }\end{array}$ & $\begin{array}{l}\text { Combined media } \\
\text { reports/autopsy and } \\
\text { medical records }\end{array}$ & SCD only & Multiple & Competitive & Portion & $17-29$ & $M$ & 8 & High \\
\hline Biasco 2013 & $\begin{array}{l}\text { Retrospective } \\
\text { Cohort }\end{array}$ & Known & $\begin{array}{l}\text { Not } \\
\text { described }\end{array}$ & Not reported & $\begin{array}{l}\text { SCA and } \\
\text { SCD }\end{array}$ & Soccer & Elite & Yes & Mean 23.6 & $M$ & 5 & High \\
\hline Boden 2013 & $\begin{array}{l}\text { Prospective } \\
\text { Cohort }\end{array}$ & Open & $\begin{array}{l}\text { Not } \\
\text { described }\end{array}$ & $\begin{array}{l}\text { Combined eyewitness } \\
\text { interview and } \\
\text { medical/autopsy } \\
\text { record }\end{array}$ & SCD only & $\begin{array}{l}\text { American } \\
\text { Football }\end{array}$ & Multiple & $\begin{array}{l}\text { Not } \\
\text { described }\end{array}$ & $14-25$ & $M$ & 6 & High \\
\hline Roberts 2013 & $\begin{array}{l}\text { Retrospective } \\
\text { Cohort }\end{array}$ & Open & Exertional & Insurance records & SCD only & Multiple & Scholastic & No & $12-19$ & $M \& F$ & 19 & High \\
\hline Maron 2016 & $\begin{array}{l}\text { Retrospective } \\
\text { Cohort }\end{array}$ & Open & All & $\begin{array}{l}\text { Combined media } \\
\text { reports/autopsy and } \\
\text { medical records }\end{array}$ & SCD only & Multiple & Competitive & $\begin{array}{l}\text { Not } \\
\text { described }\end{array}$ & $15-24$ & $M \& F$ & 10 & High \\
\hline $\begin{array}{l}\text { Santos- } \\
\text { Lozano } 2017\end{array}$ & $\begin{array}{l}\text { Retrospective } \\
\text { Cohort }\end{array}$ & Open & Exertional & Media reports & SCD only & Soccer & Elite & Portion & $16-34$ & $\begin{array}{l}\text { Not } \\
\text { reported }\end{array}$ & 21 & High \\
\hline Kucera 2018 & $\begin{array}{l}\text { Prospective } \\
\text { Cohort }\end{array}$ & Open & All & $\begin{array}{l}\text { Combined eyewitness } \\
\text { interview and } \\
\text { medical/autopsy } \\
\text { record }\end{array}$ & SCD only & $\begin{array}{l}\text { American } \\
\text { Football }\end{array}$ & Competitive & No & $<40$ & $\mathrm{M}$ & 25 & High \\
\hline Maurice 2018 & Survey & Open & Exertional & $\begin{array}{l}\text { Facility event report } \\
\text { (ex: school records) }\end{array}$ & $\begin{array}{l}\text { SCA and } \\
\text { SCD }\end{array}$ & Rugby & Competitive & No & unknown & $M \& F$ & 1 & High \\
\hline Endres 2019 & $\begin{array}{l}\text { Retrospective } \\
\text { Cohort }\end{array}$ & Open & Exertional & Media reports & SCD only & Multiple & Multiple & No & $6-17$ & $M \& F$ & 27 & High \\
\hline
\end{tabular}

\section{Table 1: Characteristics of included studies}

$S C D=S u d d e n$ cardiac death, $S C A=S u d d e n$ cardiac arrest, $M=$ Male, F=Female

Athlete categories: Elite=professional or Division 1 NCAA athletes in U.S.; Competitive= athletes participating in organized sport with practices and competitions; University=athletes competing in all levels at a university setting; Scholastic=competing for schools between middle and high school equivalents in the U.S. (approximately ages 12-19); Multiple=combination of different levels; Military=active duty military, and one study including firefighter 
medRxiv preprint doi: https://doi.org/10.1101/2020.09.13.20193714; this version posted December 24, 2020. The copyright holder for this preprint (which was not certified by peer review) is the author/funder, who has granted medRxiv a license to display the preprint in perpetuity.

It is made available under a CC-BY-NC-ND 4.0 International license .

\begin{tabular}{|c|c|c|c|c|c|c|c|c|c|}
\hline Studies & 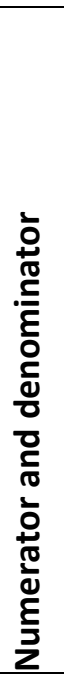 & 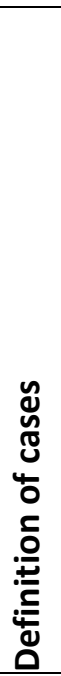 & 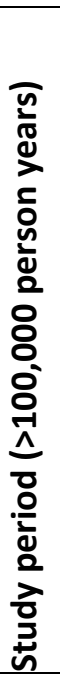 & 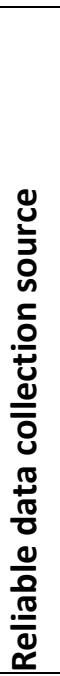 & 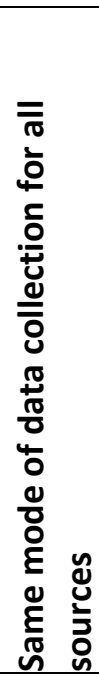 & 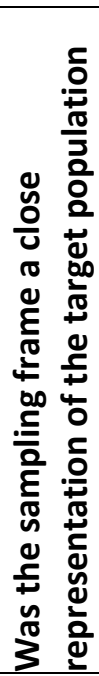 & 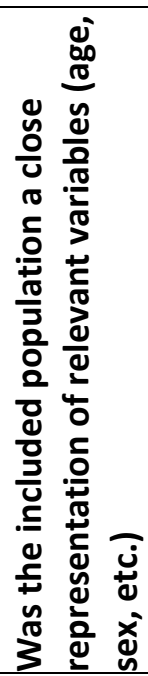 & 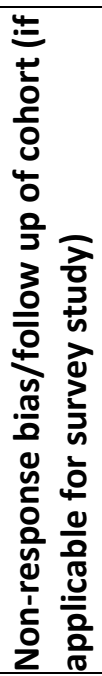 & 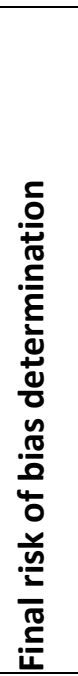 \\
\hline Koskenvuo 1976 & O & 0 & 0 & 0 & 0 & O & 0 & $\mathrm{~N} / \mathrm{A}$ & O \\
\hline Phillips 1986 & 0 & 0 & 0 & 0 & 0 & O & O & $\mathrm{N} / \mathrm{A}$ & 0 \\
\hline Assanelli 1995 & 0 & 0 & 0 & O & 0 & O & O & N/A & 0 \\
\hline Fuller 1997 & 0 & 0 & 0 & 0 & 0 & 0 & 0 & N/A & 0 \\
\hline Jordaens 1996 & O & 0 & 0 & 0 & - & O & 0 & N/A & 0 \\
\hline Maron 1998 & 0 & 0 & 0 & 0 & 0 & 0 & 0 & N/A & 0 \\
\hline Young 1999 & 0 & 0 & 0 & 0 & 0 & 0 & 0 & N/A & 0 \\
\hline Eckart 2004 & 0 & 0 & 0 & 0 & 0 & 0 & 0 & $\mathrm{~N} / \mathrm{A}$ & \\
\hline Drezner 2005 & 0 & 0 & 0 & 0 & 0 & 0 & 0 & 0 & 0 \\
\hline Corrado 2006 & 0 & 0 & 0 & 0 & 0 & 0 & 0 & $\mathrm{~N} / \mathrm{A}$ & 0 \\
\hline Chevalier 2009 & 0 & 0 & 0 & 0 & 0 & 0 & 0 & N/A & 0 \\
\hline Drezner 2009 & 0 & 0 & 0 & 0 & O & 0 & O & 0 & 0 \\
\hline Maron 2009 & 0 & 0 & 0 & 0 & 0 & 0 & 0 & $\mathrm{~N} / \mathrm{A}$ & 0 \\
\hline Holst 2010 & 0 & 0 & 0 & 0 & 0 & 0 & 0 & $\mathrm{~N} / \mathrm{A}$ & 0 \\
\hline Solberg 2010 & 0 & 0 & 0 & 0 & 0 & 0 & 0 & $\mathrm{~N} / \mathrm{A}$ & 0 \\
\hline Eckart 2011 & 0 & 0 & 0 & 0 & 0 & 0 & 0 & N/A & 0 \\
\hline Marijon 2011 & 0 & 0 & 0 & 0 & 0 & 0 & 0 & N/A & 0 \\
\hline
\end{tabular}


medRxiv preprint doi: https://doi.org/10.1101/2020.09.13.20193714; this version posted December 24, 2020. The copyright holder for this preprint (which was not certified by peer review) is the author/funder, who has granted medRxiv a license to display the preprint in perpetuity.

It is made available under a CC-BY-NC-ND 4.0 International license .

\begin{tabular}{|c|c|c|c|c|c|c|c|c|c|}
\hline Steinvil 2011 & 0 & 0 & 0 & 0 & 0 & 0 & 0 & N/A & 0 \\
\hline Durakovic 2012 & 0 & 0 & 0 & 0 & 0 & 0 & 0 & N/A & 0 \\
\hline Biasco 2013 & 0 & O & 0 & O & 0 & 0 & 0 & $\mathrm{~N} / \mathrm{A}$ & 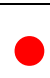 \\
\hline Boden 2013 & 0 & 0 & 0 & 0 & 0 & 0 & 0 & N/A & 0 \\
\hline Maron 2013 & 0 & 0 & 0 & 0 & 0 & 0 & 0 & N/A & 0 \\
\hline Roberts 2013 & 0 & 0 & 0 & 0 & 0 & 0 & 0 & $\mathrm{~N} / \mathrm{A}$ & 0 \\
\hline Risgaard 2014 & 0 & 0 & O & 0 & 0 & 0 & 0 & N/A & 0 \\
\hline Toresdahl 2014 & O & 0 & 0 & 0 & 0 & 0 & O & N/A & 0 \\
\hline Farioli 2015 & 0 & 0 & ○ & 0 & 0 & 0 & 0 & N/A & 0 \\
\hline Harmon 2015 & 0 & 0 & 0 & 0 & 0 & 0 & 0 & $\mathrm{~N} / \mathrm{A}$ & 0 \\
\hline Grani 2016 & 0 & 0 & 0 & 0 & 0 & 0 & 0 & N/A & O \\
\hline Harmon 2016 & 0 & 0 & 0 & 0 & 0 & 0 & 0 & $\mathrm{~N} / \mathrm{A}$ & 0 \\
\hline Maron 2016 & 0 & 0 & 0 & 0 & 0 & 0 & 0 & N/A & 0 \\
\hline Maron 2016a & 0 & 0 & 0 & 0 & 0 & O & 0 & $\mathrm{~N} / \mathrm{A}$ & O \\
\hline Smallman 2016 & 0 & 0 & 0 & 0 & 0 & 0 & 0 & $\mathrm{~N} / \mathrm{A}$ & 0 \\
\hline Landry 2017 & 0 & 0 & 0 & 0 & 0 & 0 & 0 & $\mathrm{~N} / \mathrm{A}$ & 0 \\
\hline $\begin{array}{l}\text { Santos-Lozano } \\
2017\end{array}$ & 0 & 0 & 0 & 0 & 0 & 0 & 0 & N/A & 0 \\
\hline Berge 2018 & 0 & 0 & 0 & 0 & 0 & 0 & 0 & N/A & O \\
\hline Kucera 2018 & 0 & 0 & 0 & 0 & 0 & 0 & 0 & $\mathrm{~N} / \mathrm{A}$ & 0 \\
\hline Malhotra 2018 & 0 & O & 0 & 0 & 0 & O & ○ & $\mathrm{N} / \mathrm{A}$ & 0 \\
\hline Maurice 2018 & 0 & 0 & 0 & 0 & 0 & 0 & 0 & 0 & 0 \\
\hline Endres 2019 & 0 & 0 & 0 & 0 & 0 & 0 & 0 & N/A & 0 \\
\hline Peterson 2020 & 0 & 0 & 0 & 0 & 0 & 0 & 0 & N/A & \\
\hline
\end{tabular}

Table 2: Risk of bias table for included studies reporting on incidence based on customized version of risk of bias in prevalence studies tool ${ }^{29}$.

N/A=not applicable. This section was applicable for survey projects only.

Details: - Signifies low risk of bias; signifies unclear risk of bias; •signifies high risk of bias. In the final risk of bias determination column, overall risk of bias, signifies moderate risk of bias 
medRxiv preprint doi: https://doi.org/10.1101/2020.09.13.20193714; this version posted December 24, 2020. The copyright holder for this preprint (which was not certified by peer review) is the author/funder, who has granted medRxiv a license to display the preprint in perpetuity.

It is made available under a CC-BY-NC-ND 4.0 International license . 
medRxiv preprint doi: https://doi.org/10.1101/2020.09.13.20193714; this version posted December 24, 2020. The copyright holder for this preprint (which was not certified by peer review) is the author/funder, who has granted medRxiv a license to display the preprint in perpetuity.

It is made available under a CC-BY-NC-ND 4.0 International license .

\begin{tabular}{|c|c|c|c|c|c|}
\hline Study/yr & Events & $\begin{array}{l}\text { Person } \\
\text { Years }\end{array}$ & $\begin{array}{l}\text { Events per } 100000 \\
\text { person-years }\end{array}$ & Events & $95 \%-\mathrm{Cl}$ \\
\hline \multicolumn{6}{|l|}{ Low risk of bias } \\
\hline Phillips 1986 & 21 & 184819.00 & $\longrightarrow$ & 11.36 & {$[7.41 ; 17.43]$} \\
\hline Corrado 2006 & 55 & $2938730.00+$ & & 1.87 & {$[1.44 ; 2.44]$} \\
\hline Holst 2010 & 15 & $1239493.00+$ & & 1.21 & {$[0.73 ; 2.01]$} \\
\hline Eckart 2011 & 298 & 10250000.00 & & 2.91 & {$[2.60 ; 3.26]$} \\
\hline Marijon 2011 & 50 & $5076465.00+$ & & 0.98 & {$[0.75 ; 1.30]$} \\
\hline Risgaard 2014 & 3 & $638298.00+$ & & 0.47 & {$[0.15 ; 1.46]$} \\
\hline Farioli 2015 & 14 & $342877.00+$ & + & 4.08 & {$[2.42 ; 6.89]$} \\
\hline Harmon 2015 & 79 & $4242519.00+$ & & 1.86 & [ $1.49 ; 2.32]$ \\
\hline Smallman 2016 & 63 & $6425421.00+$ & & 0.98 & {$[0.77 ; 1.26]$} \\
\hline Landry 2017 & 7 & $1379574.00+$ & & 0.51 & {$[0.24 ; 1.06]$} \\
\hline Malhotra 2018 & 8 & 118351.00 & 1 & 6.76 & {$[3.38 ; 13.52]$} \\
\hline Peterson 2020 & 96 & $13437888.00+$ & & 0.71 & {$[0.58 ; 0.87]$} \\
\hline \multicolumn{6}{|c|}{ Heterogeneity: $\chi_{11}^{2}=304.29(p<0.01)$} \\
\hline \multicolumn{6}{|l|}{ Moderate risk of bias } \\
\hline Koskenvuo 1976 & 16 & $660000.00+$ & & 2.42 & {$[1.49 ; 3.96]$} \\
\hline Maron 1998 & 3 & $651695.00+$ & & 0.46 & {$[0.15 ; 1.43]$} \\
\hline Young 1999 & 6 & $299985.00+$ & & 2.00 & {$[0.90 ; 4.45]$} \\
\hline Drezner 2005 & 5 & $330736.00+$ & & 1.51 & {$[0.63 ; 3.63]$} \\
\hline Maron 2013 & 13 & $1930504.00+$ & & 0.67 & {$[0.39 ; 1.16]$} \\
\hline Toresdahl 2014 & 2 & 1500000.00 & & 0.13 & {$[0.03 ; 0.53]$} \\
\hline Grani 2016 & 145 & 2032730.00 & + & 7.13 & {$[6.06 ; 8.39]$} \\
\hline Harmon 2016 & 69 & $6974640.00+$ & & 0.99 & {$[0.78 ; 1.25]$} \\
\hline Maron 2016a & 3 & $361841.00+$ & & 0.83 & {$[0.27 ; 2.57]$} \\
\hline Berge 2018 & 0 & 4760.00 & + & 10.50 & {$[0.66 ; 167.94]$} \\
\hline \multicolumn{6}{|c|}{ Heterogeneity: $\chi_{9}^{2}=262.35(p<0.01)$} \\
\hline \multicolumn{6}{|l|}{ High risk of bias } \\
\hline Assanelli 1995 & 5 & 16000.00 & & 31.25 & {$[13.01 ; 75.08]$} \\
\hline Jordaens 1996 & 14 & 15722.00 & & 89.05 & {$[52.74 ; 150.35]$} \\
\hline Fuller 1997 & 0 & 16782.00 & & 2.98 & {$[0.19 ; 47.63]$} \\
\hline Eckart 2004 & 64 & 969231.00 & + & 6.60 & {$[5.17 ; 8.44]$} \\
\hline Chevalier 2009 & 12 & $1096240.00+$ & & 1.09 & {$[0.62 ; 1.93]$} \\
\hline Drezner 2009 & 5 & $317205.00 \div$ & & 1.58 & {$[0.66 ; 3.79]$} \\
\hline Maron 2009 & 19 & $1578872.00+$ & & 1.20 & {$[0.77 ; 1.89]$} \\
\hline Solberg 2010 & 23 & $2597204.00+$ & & 0.89 & [ $0.59 ; 1.33]$ \\
\hline Steinvil 2011 & 22 & $923077.00+$ & & 2.38 & {$[1.57 ; 3.62]$} \\
\hline Durakovic 2012 & 6 & $3133512.00+$ & & 0.19 & {$[0.09 ; 0.43]$} \\
\hline Biasco 2013 & 0 & 4495.00 & + & 11.12 & {$[0.70 ; 177.84]$} \\
\hline Boden 2013 & 100 & 24100754.00 & & 0.41 & {$[0.34 ; 0.50]$} \\
\hline Roberts 2013 & 4 & $1666509.00+$ & & 0.24 & {$[0.09 ; 0.64]$} \\
\hline Maron 2016 & 842 & 165705417.00 & & 0.51 & {$[0.47 ; 0.54]$} \\
\hline Santos-Lozano 2017 & 20 & $1923076.00+$ & & 1.04 & {$[0.67 ; 1.61]$} \\
\hline Kucera 2018 & 10 & $1175000.00+$ & & 0.85 & {$[0.46 ; 1.58]$} \\
\hline Maurice 2018 & 2 & $408750.00+$ & & 0.49 & {$[0.12 ; 1.96]$} \\
\hline Endres 2019 & 34 & 185792350.00 & & 0.02 & {$[0.01 ; 0.03]$} \\
\hline \multicolumn{6}{|c|}{ Heterogeneity: $\chi_{17}^{2}=1334.61(p<0.01)$} \\
\hline \multicolumn{4}{|c|}{ Heterogeneity: $\chi_{39}^{2^{\prime}}=2793.36(p=0)$} & 1 & \\
\hline Residual heterogeneity: & $x_{37}^{2}=190$ & $1.25(p=0)$ & 20 & 30 & \\
\hline
\end{tabular}

Figure 2: Incidence rates of sudden cardiac death (SCD) reported by included studies. 


\section{Study/yr \\ Low risk of bias}

\section{Events}

$13 \quad 1379574.00$

24315417886.00

Peterson 2020

Heterogeneity: $\chi_{1}^{2}=3.26(p=0.07)$

\section{Moderate risk of bias}

Drezner 2005

Toresdahl 2014

$\begin{array}{rr}5 & 330736.00+ \\ 18 & 1500000.00+ \\ 104 & 6974640.00 \\ 3 & 4760.00\end{array}$

Berge 2018

Heterogeneity: $\chi_{3}^{2}=42.48(p<0.01)$

\section{Person \\ Years \\ Events per 100000 \\ person-years}

$95 \%-\mathrm{Cl}$

$0.94 \quad[0.55 ; 1.62]$

$1.58 \quad[1.39 ; 1.79]$

\section{High risk of bias}

Assanelli 1995

Fuller 1997

Drezner 2009

Maron 2009

Steinvil 2011

Maurice 2018

7

7

16000.00

16782.00

$14 \quad 317205.00$

$23 \quad 1578872.00$

$24 \quad 923077.00$

$7 \quad 408750.00$

Heterogeneity: $\chi_{5}^{2}=67.51(p<0.01)$

Heterogeneity: $\chi_{11}^{2}=142.00(p<0.01)$

Residual heterogeneity: $\chi_{9}^{2}=113.26(p<\infty 01)$

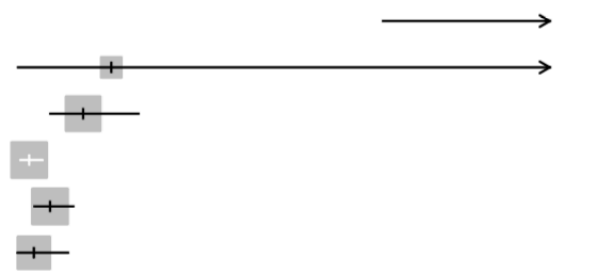

10
$1.51 \quad$ [ 0.63; 3.63]

$1.20 \quad$ [0.76; 1.90]

$1.49 \quad[1.23 ; 1.81]$

$63.03[20.33 ; 195.41]$
43.75 [20.86; 91.77]
$5.96 \quad[0.84 ; 42.30]$
$4.41 \quad$ [2.61; 7.45]
$1.46 \quad[0.97 ; 2.19]$
$2.60 \quad[1.74 ; 3.88]$
1.71 [ 0.82; 3.59]

Figure 3: Incidence rates of sudden cardiac arrest (SCA) in reported by included studies 


\section{Population based studies}

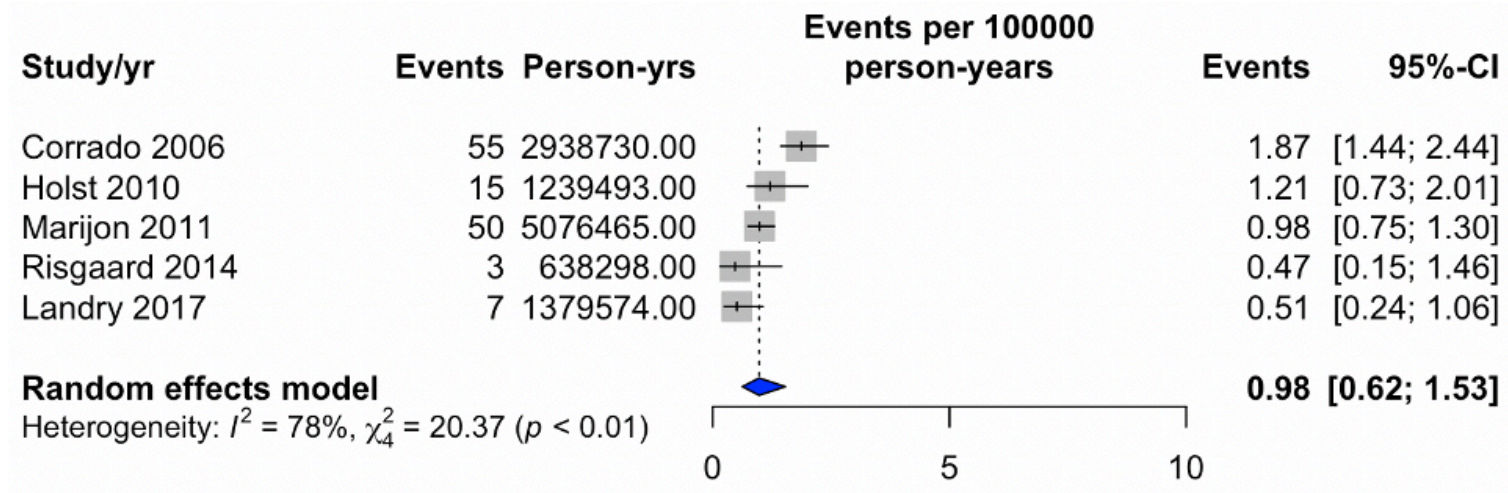

\section{Studies with competitive athletes}

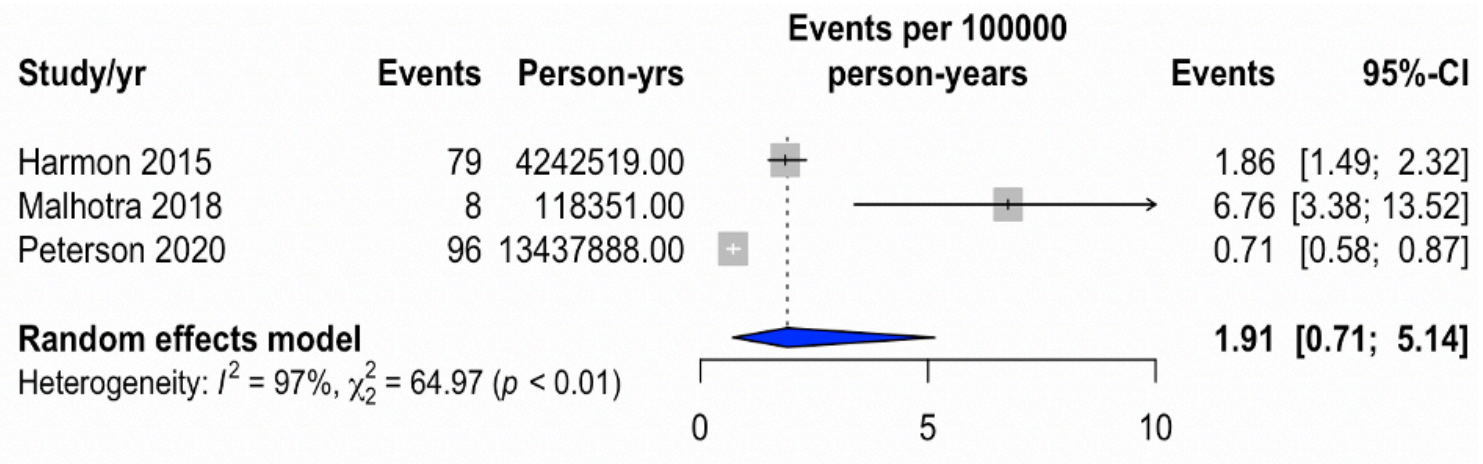

Figure 4: Meta-analyses of incidence rate of sudden cardiac death in low risk of bias studies taking place at population levels, and in studies in competitive athletes between the ages of 14-25. 